\title{
Solid phase synthesis of 5,6-disubstituted pyrimidinone and pyrimidindione derivatives
}

\author{
Maria Cristina Parlato, Claudia Mugnaini, Michela Lucia Renzulli, Federico Corelli*, and \\ Maurizio Botta* \\ Dipartimento Farmaco Chimico Tecnologico, \\ Università degli Studi di Siena, Via A. Moro 53100 Siena, Italy \\ E-mail: botta@unisi.it,corelli@unisi.it
}

\begin{abstract}
Dedicated to Prof. Vincenzo Tortorella on the occasion of his "Fuori Ruolo" status
(received 02 Feb 04; accepted 04 May 04; published on the web 05 May 04)
\end{abstract}

\begin{abstract}
Solid phase synthesis of 5,6-disubstituted pyrimidinone and pyrimidindione derivatives by the use of the Syncore ${ }^{\circledR}$ Reactor is described starting from easily available building blocks.
\end{abstract}

Keywords: Antiviral agents, pyrimidinones, pyrimidindiones, solid phase synthesis

\section{Introduction}

In the last few years pyrimidinone and pyrimidindione derivatives substituted either at the C-5 and C-6 position have emerged in the field of chemotherapy. ${ }^{1}$ Among the important 6-substituted uracil derivative HEPT and its analogues, ${ }^{2}$ Emivirine (EMV) ${ }^{3}$ has been chosen as a candidate for clinical trials, and DABOs, ${ }^{4}$ showed a potent and selective activity against HIV-1 (Figure 1).

In this context, the finding that C-6 substituted pyrimidinone and pyrimidindione derivatives showed selective antitumor, ${ }^{5}$ antiviral, ${ }^{6}$ antitubercular, ${ }^{7}$ antifungal activity, ${ }^{8}$ suggests the importance of testing this family of compounds as broad-spectrum drugs.

In the last few years, we have been involved in the synthesis and biological evaluation of new pyrimidindione and pyrimidinone derivatives as potential antitumor and antiviral agents. ${ }^{9} \mathrm{We}$ have described ${ }^{10}$ one of the most reliable synthesis of 2-methoxy and 2-thiomethyl 5,6disubstituted pyrimidinone derivatives by condensation of $O$-methylisourea, or $S$ methylisothiourea with $\beta$-ketoesters in $\mathrm{H}_{2} \mathrm{O} / \mathrm{EtOH}$ mixture in the presence of $\mathrm{Ca}(\mathrm{OH})_{2}$. Their versatility to be transformed into uracils, ${ }^{9 \mathrm{i}, 10}$ and thiouracils ${ }^{9 \mathrm{i}}$ has also been shown. By modification of the substitution in virtually all the six positions of the pyrimidinone nucleus we 
were able to synthesize compounds provided with interesting activity against HIV-1, ${ }^{9 \mathrm{~g}} \mathrm{ASFV},{ }^{11}$ Sendai virus $^{9 \mathrm{~g}}$ and Rubella virus. ${ }^{9 \mathrm{i}, 12}$<smiles>Cc1c(Sc2ccccc2)n(COCCO)c(=O)[nH]c1=O</smiles>

HEPT<smiles>CCOCn1c(Cc2ccccc2)c(C(C)C)c(=O)[nH]c1=O</smiles>

Emivirine (EMV)<smiles></smiles>

S-DABOs<smiles>[R]C=CC=C(C=C[R1])Cc1nc(O[R2])[nH]c(=O)c1[R]</smiles>

DABOs

Figure 1. 5,6-Disubstituted pyrimidinone and pyrimidindione derivatives endowed with potent antiviral activity

Combinatorial chemistry, a technique that allows the synthesis of large numbers of molecules by varying combinations and permutations of modular components, has changed the nature of chemical discovery. ${ }^{13}$ Solid-phase synthesis (SPS) ${ }^{14}$ is playing a decisive role in the ongoing development of combinatorial chemistry, mainly because it offers striking advantages in terms of synthetic flexibility, such as: (i) the ease of chemistry; (ii) the possibility of using high concentrations of reagents to drive reactions to completion; (iii) the elimination of purification steps en route, since impurities and excess reagents can be removed by simple washing of the solid support; (iv) the straightforward nature of parallel SPS; (v) the possibility of automation.

Based on these observations, our efforts were directed towards the elaboration of combinatorial methods, to be developed on solid support, which take advantage of the synthetic strategy elaborated in our laboratories, and the use of a semiautomatic synthesizer for generating pyrimidinone derivatives substituted either at C-5 and C-6.

\section{Results and Discussion}

We have already described ${ }^{9 f}$ a versatile solid phase approach for the synthesis of a series of pyrimidinone derivatives. In the key step, a polymer-bound thiouronium salt $\mathbf{1}$ is condensed with different $\beta$-ketoesters by adding an excess of $\mathrm{Ca}(\mathrm{OH})_{2}$ in water-ethanol solution (Scheme 1). 


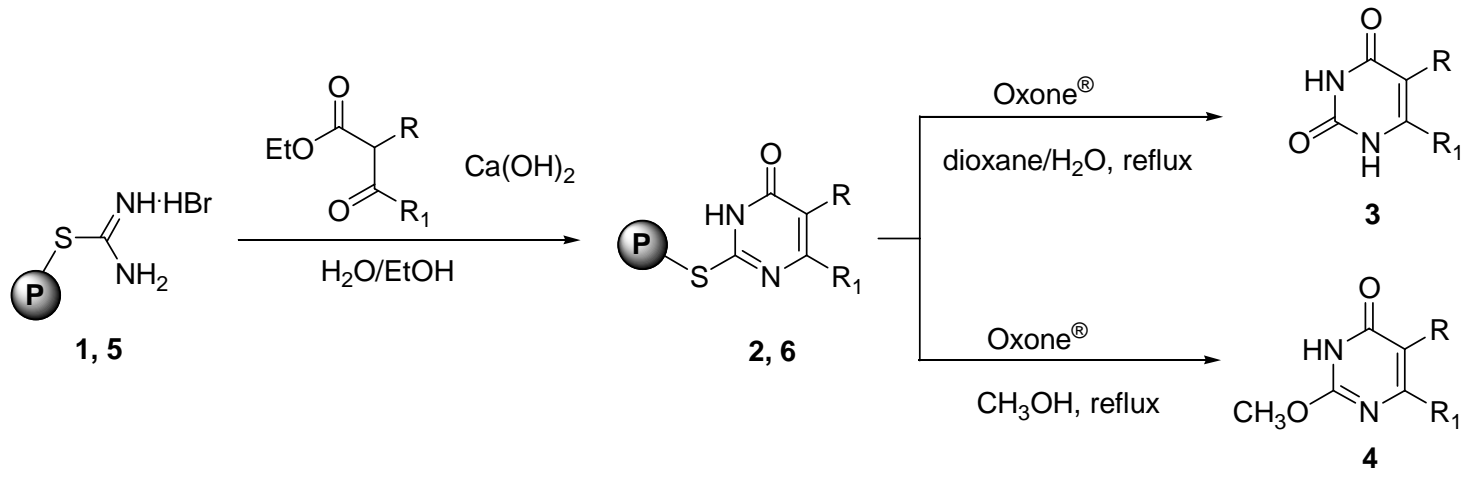

1-2 $\mathrm{P}=$<smiles>CCCCCOCc1ccc(I)cc1</smiles>

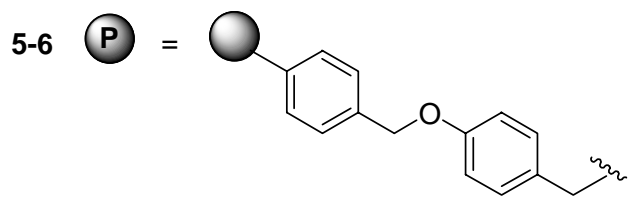

Yield (\%)

\begin{tabular}{lllll}
\hline Compd & $\mathrm{R}$ & $\mathrm{R}_{1}$ & From 2 & From 6 \\
\hline 3a & $\mathrm{H}$ & $\mathrm{CH}_{3}$ & 98 & 95 \\
3b & $\mathrm{CH}$ & $\mathrm{CH}_{3}$ & 83 & 78 \\
3c & $\mathrm{H}$ & $\mathrm{CH}_{2} \mathrm{Ph}$ & 85 & 70 \\
3d & $\mathrm{H}$ & $\mathrm{CH}_{2} \mathrm{COOEt}$ & 78 & 65 \\
4a & $\mathrm{H}$ & $\mathrm{CH}_{3}$ & 95 & 96 \\
4b & $\mathrm{CH}_{3}$ & $\mathrm{CH}_{3}$ & 72 & 70 \\
4c & $\mathrm{H}$ & $\mathrm{CH}_{2} \mathrm{Ph}$ & 77 & 73 \\
4d & $\mathrm{H}$ & $\mathrm{CH}_{2} \mathrm{COOEt}$ & 67 & 56 \\
\hline
\end{tabular}

Scheme 1. Solid phase synthesis of 5,6-disubstituted-pyrimidindiones 3 and 2-methoxypyrimidinones $\mathbf{4}$ using two different solid supports.

As result, the corresponding pyrimidinone system 2 is anchored to the solid support (Merrifield resin) through a tetramethylene spacer which is important in order to create a "chemical distance" between the uracil nucleus and the polymer backbone, to confer more "solution like" properties and better solvent compatibility to the resin. The resulting thio-ether bond is stable to alkaline conditions, nucleophilic attack and is fairly stable to acids, so that the uracil moiety can be easily derivatized before being cleaved from the solid support. It is well known that $n$-alkyl thioethers are difficult to be cleaved and hence have not been extensively used as protecting groups; as a result, the most important issue to be addressed was the 
identification of a suitable cleavage methodology. In the literature many cleavage methodologies have been reported ${ }^{7 b, 15}$ which proved to be unsuccessfull for the cleavage of polymer-bound pyrimidinones 2. Oxone ${ }^{\circledR}$, potassium hydrogen persulfate, is a reagent used for the oxidation of sulfides to sulfones. Treating 2 with Oxone ${ }^{\circledR}$, in a solution of dioxane/ $\mathrm{H}_{2} \mathrm{O}$ at reflux temperature, a very reactive sulphone intermediate is obtained which is then subjected to nucleophilic attack by water leading to the cleavage of the uracil derivative $3 .^{9 \mathrm{e}}$ Accordingly, when the oxidation with Oxone ${ }^{\circledR}$ is performed in a methanolic solution, 2-methoxy derivatives 4 are obtained.

Considering the difficulties encountered in the cleavage step, we turned our attention to the use of the Wang resin characterized by the presence of a benzylic spacer, extensively used as a protecting group for thio groups. The polymer-bound thiouronium salt $\mathbf{5}$, obtained following a procedure developed in our laboratories, ${ }^{9 e, f}$ was condensed with different $\beta$-ketoesters (50 equiv) in a water-ethanol mixture affording the corresponding pyrimidinones 6. Oxone ${ }^{\circledR}$ cleavage procedure applied to $\mathbf{6}$ gave compounds $\mathbf{3}$ and $\mathbf{4}$ in comparable yields.

As a consequence of be using the acid labile Wang linker, the corresponding 2-thio uracils 7 (Scheme 2) could be accessed from $\mathbf{6}$, in similar yield and purity that $\mathbf{3}$ and $\mathbf{4}$, by a benzylic-type cleavage using 5\% TFA in $\mathrm{CH}_{2} \mathrm{Cl}_{2}$.

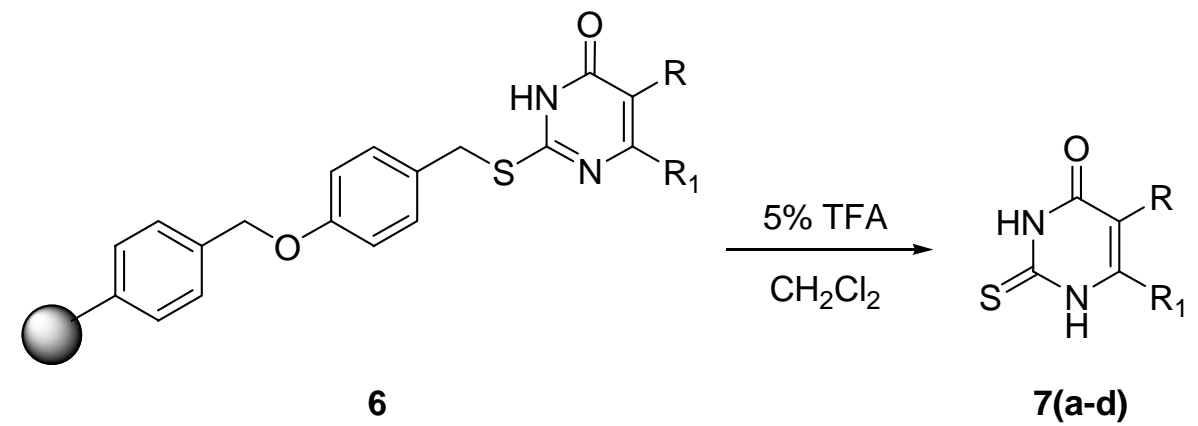

\begin{tabular}{llll}
\hline Compd & $\mathrm{R}$ & $\mathrm{R}_{1}$ & Yield (\%) \\
\hline 7a & $\mathrm{H}$ & $\mathrm{CH}_{3}$ & 78 \\
7b & $\mathrm{CH}_{3}$ & $\mathrm{CH}_{3}$ & 70 \\
7c & $\mathrm{H}$ & $\mathrm{CH}_{2} \mathrm{Ph}$ & 80 \\
7d & $\mathrm{H}$ & $\mathrm{CH}_{2} \mathrm{COOEt}$ & 72 \\
\hline
\end{tabular}

Scheme 2. Synthesis of 5,6-disubstituted-2-thio pyrimidinones 7.

The cleavage with greater amounts of TFA (10\% and $25 \%)$ gave mixtures of compounds $7 \mathbf{a}$ and 8 (Scheme 3) characterized by the presence of growing percentages of $\mathbf{8}$.

Considering that Merrifield and Wang resins are hydrophobic in nature, whereas the cyclization reaction and the Oxone ${ }^{\circledR}$ cleavage were performed in polar solvent (water, ethanol), Tentagel ${ }^{\circledR}$ 
resin was finally investigated for pyrimidinones synthesis as this polymer is quite hydrophilic and readily solvated by polar solvents.

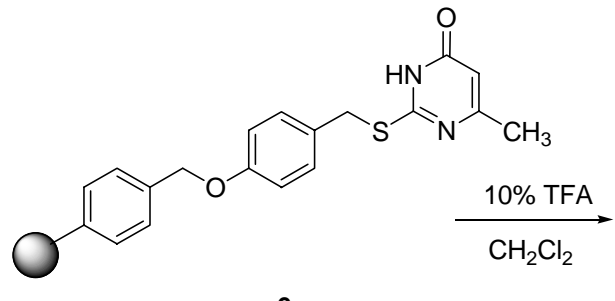

$6 a$

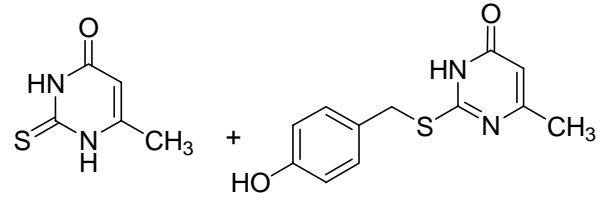

$7 a$

Scheme 3. Cleavage of 2-thio-6-methyluracil by the use of $10 \%$ TFA.

Unfortunately, Oxone $^{\circledR}$ cleavage methodology applied to Tentagel ${ }^{\circledR}$ resin supported pyrimidinones afforded the desired compounds in poor yields together with byproducts derived from the degradation of the solid support itself.

As described in Scheme 1, treating the polymer supported thiouronium salt 5 with different $\beta$ ketoesters afforded highly diverse pyrimidinones 6 substituted at positions 5 and 6 , due to the incorporation of different $\beta$-ketoester residues. The use of three different cleavage methodologies gave differently modified pyrimidinones at position 2 . This provides a good centre of diversity for producing libraries in the search of lead identification and lead optimization.

The use of three different cleavage methodologies to pyrimidinones 6 gave differently modified pyrimidinones at 2 . This provides a good centre of diversity for producing libraries in the search of lead identification and lead optimization.

The availability of a large number of diverse $\beta$-ketoesters, which can be either commercially available or easily prepared in a few steps from commercial starting materials, makes them good building-blocks. Moreover, the easiness of synthetic methodologies of this solid phase protocol provides the possibility of automation of reactions.

As a result, we have focused our attention on a parallel version of this synthesis by using a Buchi Syncore ${ }^{\circledR}$ Reactor. This semiautomatic synthesizer is an instrument able to provide up to 24 reactions in parallel, comprehending the vacuum evaporation steps, filtration and washing of the resins, without cross contamination problems and avoiding some boring passages, with final huge time recovery. The vortex/shaking system provided for the Syncore ${ }^{\circledR}$ ensures complete mixing of the samples without the use of a stirrer which could damage delicate solid-phase beads.

Our first approach was the search of the ideal conditions to optimize the cyclization reaction on the resin in the Syncore ${ }^{\circledR}$. This is, in fact, a tricky point being the step from the flask to the Syncore $^{\circledR}$ not so straightforward.

In a classical experiment, cyclization was performed in the presence of $\mathrm{Ca}(\mathrm{OH})_{2}$ in a $1: 1$ mixture ethanol: water $\left(25 \mathrm{ml}\right.$ for $500 \mathrm{mg}$ of Wang resin) at $25^{\circ} \mathrm{C}$ for six days using 50 equivalents of $\beta$-ketoester. Under these conditions 6-methyluracil was obtained in $95 \%$ yield after oxidation and nucleophilic cleavage by water. 
Therefore the cyclization step suffers from some drawbacks such as: (i) long time of reaction (six days), (ii) large excess of $\beta$-ketoesters (50 equivalent are very expensive!), (iii) large amount of solvent. Cyclization performed under the same experimental conditions by using Syncore ${ }^{\circledR}$ (the vortex/shaking system provided for the Syncore ${ }^{\circledR}$ is unable to stir a great mass of solvent) afforded 6-methyl uracil in low yield $(62 \%)$ after Oxone ${ }^{\circledR}$ cleavage in dioxane $/ \mathrm{H}_{2} \mathrm{O}$.

It was therefore noticed that the Syncore ${ }^{\circledR}$ vortex/shaking system was unable to maintain the polymer and $\mathrm{Ca}(\mathrm{OH})_{2}$ suspended in the solvent mixture and three different layers could be clearly observed in the reaction vessel: the resin on the bottom, a white layer of $\mathrm{Ca}(\mathrm{OH})_{2}$ and a large mass of solvent on the top. The $\mathrm{pH}$ of the reaction was observed to be 5 all the time.

A few points were then taken into consideration to improve the yield: (i) reduction of the solvent amount and $\beta$-ketoester equivalents, (ii) study of the effect of a soluble base $(\mathrm{NaOH})$ on the reaction course, with constant monitoring of the $\mathrm{pH}$ of the solution, to avoid hydrolysis of $\beta$ ketoesters, (iii) use of dioxane as co-solvent in order to improve the swelling of the resin, (iv) study of the effect of the time on the cyclization reaction.

All the effects of these variables were studied at the same time, by preparing nine resins and using Syncore ${ }^{\circledR}$ according to Scheme 4.

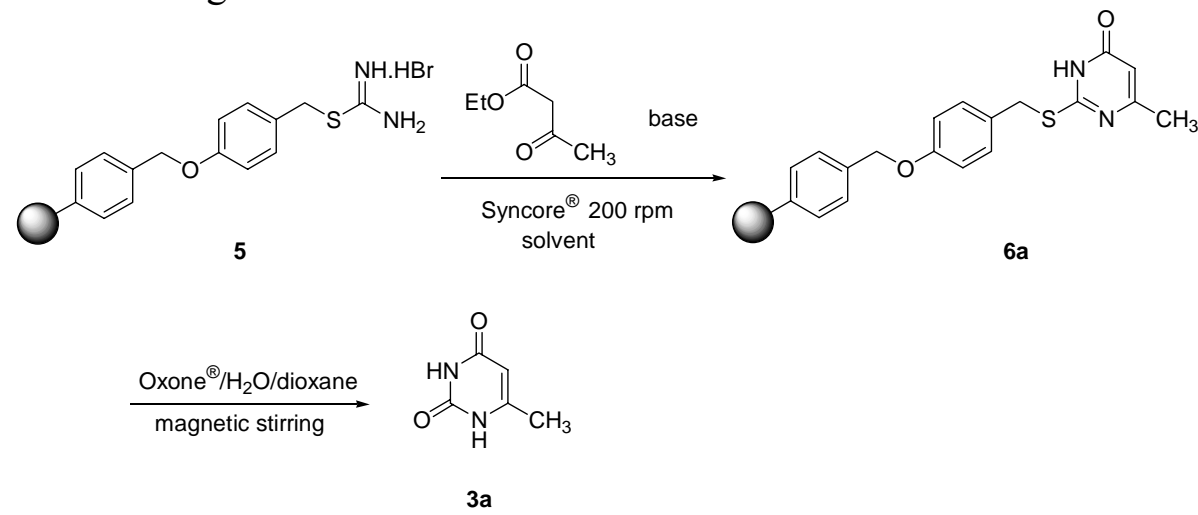

Scheme 4. Optimization of the cyclization reaction by the use of Syncore ${ }^{\circledR}$ Reactor.

Table 1. Results of the optimization of the cyclization reaction by the use of Syncore ${ }^{\circledR}$ Reactor

\begin{tabular}{|c|c|c|c|c|c|}
\hline Entry & Solvent & Base & Time & $\mathrm{pH}$ & $\begin{array}{l}\text { Yield of 6- } \\
\text { methyluracil (\%) }\end{array}$ \\
\hline $\mathbf{a}$ & $\mathrm{H}_{2} \mathrm{O} / \mathrm{EtOH}, 1 / 1$ & $\mathrm{Ca}(\mathrm{OH})_{2}$ & 24 & 9 & 84 \\
\hline b & $\mathrm{H}_{2} \mathrm{O} / \mathrm{EtOH}, 1 / 1$ & $\mathrm{Ca}(\mathrm{OH})_{2}$ & 72 & 9 & 72 \\
\hline c & $\mathrm{H}_{2} \mathrm{O} / \mathrm{EtOH}, 1 / 1$ & $\mathrm{Ca}(\mathrm{OH})_{2}$ & $72+48$ & 9 & 66 \\
\hline d & $\mathrm{H}_{2} \mathrm{O} / \mathrm{EtOH} /$ dioxane, $1 / 1 / 1$ & $\mathrm{Ca}(\mathrm{OH})_{2}$ & 24 & 9 & 86 \\
\hline $\mathbf{e}$ & $\mathrm{H}_{2} \mathrm{O} / \mathrm{EtOH} /$ dioxane, $1 / 1 / 1$ & $\mathrm{Ca}(\mathrm{OH})_{2}$ & 72 & 10 & 74 \\
\hline $\mathbf{f}$ & $\mathrm{H}_{2} \mathrm{O} / \mathrm{EtOH} /$ dioxane, $1 / 1 / 1$ & $\mathrm{Ca}(\mathrm{OH})_{2}$ & $72+48$ & 9 & 66 \\
\hline g & $\mathrm{H}_{2} \mathrm{O} / \mathrm{EtOH} /$ dioxane, $1 / 1 / 1$ & $\mathrm{NaOH}$ & 24 & 10 & 89 \\
\hline $\mathbf{h}$ & $\mathrm{H}_{2} \mathrm{O} / \mathrm{EtOH} /$ dioxane, $1 / 1 / 1$ & $\mathrm{NaOH}$ & 72 & $10 \rightarrow 8$ & 83 \\
\hline i & $\mathrm{H}_{2} \mathrm{O} / \mathrm{EtOH} /$ dioxane, $1 / 1 / 1$ & $\mathrm{NaOH}$ & $72+48$ & $10 \rightarrow 8 / 10$ & 50 \\
\hline
\end{tabular}


Each trial was performed on $500 \mathrm{mg}$ of resin, suspended in $6 \mathrm{ml}$ of solvent and using 5 equivalents of ethyl acetoacetate. The loading of the resin 6 a was, in all cases, established by the cleavage of 6-methyl uracil by treatment with Oxone ${ }^{\circledR}$ using dioxane $/ \mathrm{H}_{2} \mathrm{O}$ as solvents. In order to drive reaction to completion, the cleavage step, performed in a flask, was repeated twice under the same experimental conditions. After the cleavage the yield of 6-methyl uracil was determined and used as discriminant.

In three experiments the cyclization reaction was performed in an ethanol:water mixture in the presence of $\mathrm{Ca}(\mathrm{OH})_{2}$ at $25^{\circ} \mathrm{C}$. The reaction was carried on for $24 \mathrm{~h}$ (entry a) and $72 \mathrm{~h}$ (entry b) respectively; in the third experiment (entry c) the cyclization was performed for $72 \mathrm{~h}$ then the resin was filtered and the cyclization step was repeated under the same experimental condition for $48 \mathrm{~h}$.

In another set of three experiments (entries d-f) the cyclization reaction was performed in a similar fashion but using dioxane as co-solvent in order to improve the swelling of the resin. We observed that $\mathrm{Ca}(\mathrm{OH})_{2}$ is not completely soluble in this solvent mixture and that a $\mathrm{pH}$ of 9 was maintained all of the time.

In another two experiments the cyclization reaction was performed in the presence of $\mathrm{NaOH}$ in an ethanol:water:dioxane mixture at $25^{\circ} \mathrm{C}$ for $24 \mathrm{~h}$ (entry g) and $72 \mathrm{~h}$ (entry h). $\mathrm{NaOH}$ is completely soluble in this solvent mixture; the $\mathrm{pH}$ was determined to be 10 the first day, decreasing to 8 during the other days. In a third experiment (entry i) the cyclization was performed for $72 \mathrm{~h}$, then the resin was filtered and a further cyclization step was performed in the same experimental conditions for $48 \mathrm{~h}$ at $\mathrm{pH} 10$.

As we can observe in Table 1, reduction of solvent amounts improved the loading of 6methyluracil on the resin, whereas a long time of reaction decreased the yield; in fact better yields were obtained after only one day under all experimental conditions. The use of dioxane as co-solvent in order to improve the swelling of the resin did not improve the loading significantly.

Considering that cyclization on a polymer-bound thiouronium salt 5 in presence of $\mathrm{NaOH}$ in $\mathrm{H}_{2} \mathrm{O} / \mathrm{EtOH} /$ dioxane at $25^{\circ} \mathrm{C}$ for $24 \mathrm{~h}$ (entry g) resulted to be the best choice using a Syncore ${ }^{\circledR}$ Reactor, we then focused our attention on the synthesis of a small collection of molecules using a parallel approach. Compound 5 was treated with different substituted $\beta$-ketoesters (Scheme 5) under the former conditions to afford compounds 6. The resulting polymer-bound 5,6disubstituted pyrimidinones were then cleaved from the resin employing the three multidirectional cleavage strategies (both in the flask and using Syncore ${ }^{\circledR}$ ) leading to the final products 3,4 , and 7 in good to excellent yields.

In conclusion, diverse uracils and thiouracils were obtained with this methodology in comparable yields with that which has been described, with the advantage of using a smaller amount of $\beta$-ketoester (10 times less) and in a shorter time (1 day instead of 6). 


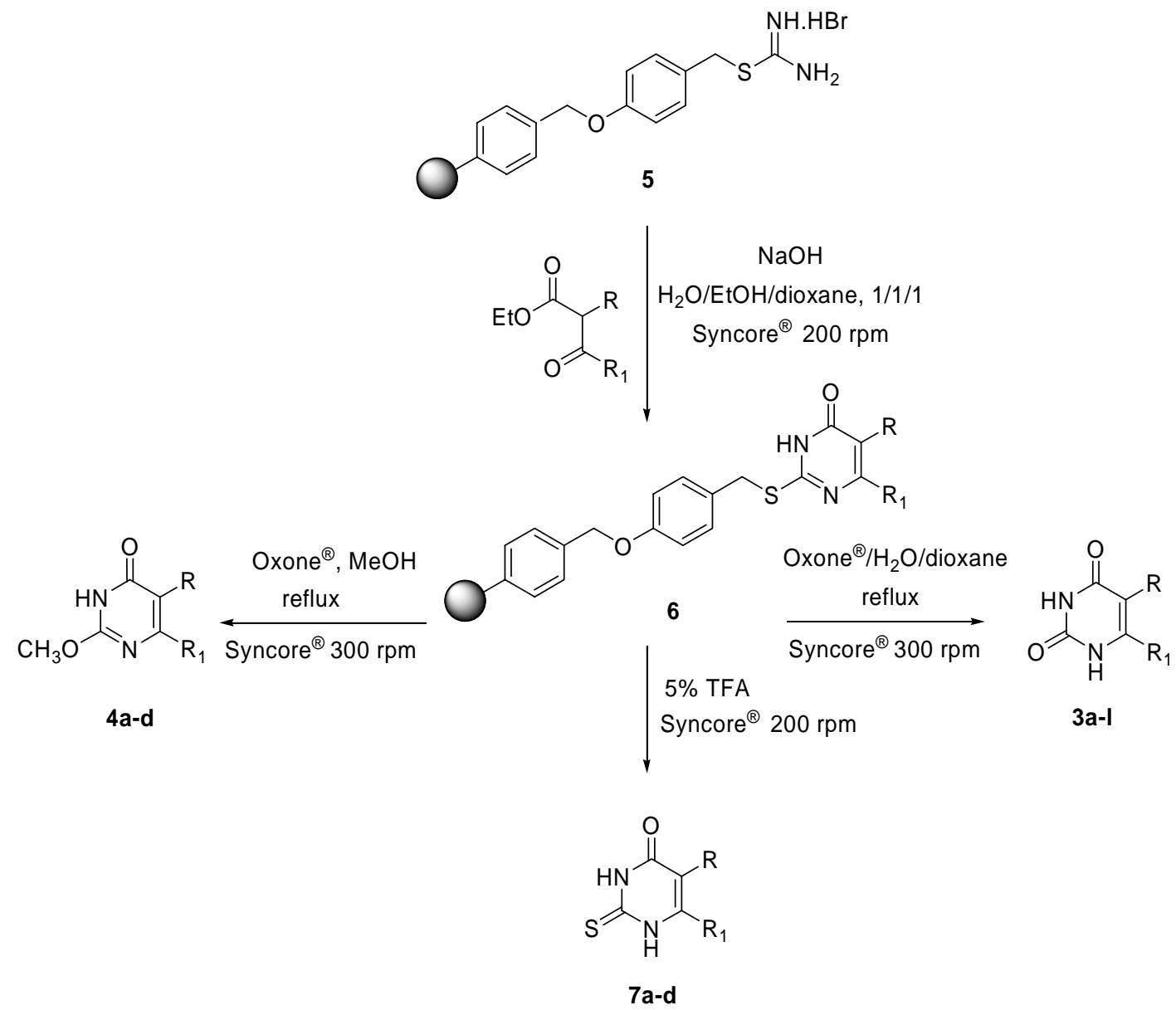

Scheme 5. Synthesis of compounds 3,4 and 7 by the use of Syncore ${ }^{\circledR}$ Reactor.

Table 2. Small library of pyrimidinone, 2-thiopyrimidinone and 2-methoxy-pyrimidinone derivatives

\begin{tabular}{|c|c|c|c|c|c|c|c|}
\hline Compd & $\mathrm{R}$ & $\mathrm{R}_{1}$ & Yield $(\%)$ & Compd & $\mathrm{R}$ & $\mathrm{R}_{1}$ & Yield $(\%)$ \\
\hline За & $\mathrm{H}$ & $\mathrm{CH}_{3}$ & 88 & $4 a$ & $\mathrm{H}$ & $\mathrm{CH}_{3}$ & 85 \\
\hline $3 \mathbf{b}$ & $\mathrm{CH}_{3}$ & $\mathrm{CH}_{3}$ & 77 & $4 b$ & $\mathrm{CH}_{3}$ & $\mathrm{CH}_{3}$ & 79 \\
\hline $3 c$ & $\mathrm{H}$ & $\mathrm{CH}_{2} \mathrm{Ph}$ & 85 & $4 c$ & $\mathrm{H}$ & $\mathrm{CH}_{2} \mathrm{Ph}$ & 81 \\
\hline 3d & $\mathrm{H}$ & $\mathrm{CH}_{2} \mathrm{COOEt}$ & 75 & $4 d$ & $\mathrm{H}$ & $\mathrm{CH}_{2} \mathrm{COOEt}$ & 73 \\
\hline $3 e$ & $\mathrm{Cl}$ & $\mathrm{CH}_{3}$ & 89 & $7 a$ & $\mathrm{H}$ & $\mathrm{CH}_{3}$ & 78 \\
\hline $3 f$ & $\mathrm{CH}_{2} \mathrm{CH}_{3}$ & $\mathrm{CH}_{3}$ & 74 & $7 b$ & $\mathrm{CH}_{3}$ & $\mathrm{CH}_{3}$ & 70 \\
\hline $3 g$ & $\mathrm{H}$ & $\mathrm{CH}_{2} \mathrm{CH}_{3}$ & 74 & 7c & $\mathrm{H}$ & $\mathrm{CH}_{2} \mathrm{Ph}$ & 80 \\
\hline $3 h$ & $\mathrm{H}$ & $\mathrm{CH}\left(\mathrm{CH}_{3}\right)_{2}$ & 65 & 7d & $\mathrm{H}$ & $\mathrm{CH}_{2} \mathrm{COOEt}$ & 72 \\
\hline $3 \mathbf{i}$ & $\mathrm{H}$ & $\mathrm{C}\left(\mathrm{CH}_{3}\right)_{3}$ & 71 & & & & \\
\hline 3j & $\mathrm{H}$ & & 69 & & & & \\
\hline $3 \mathbf{k}$ & $\mathrm{F}$ & $\mathrm{CH}_{3}$ & 99 & & & & \\
\hline 31 & $\mathrm{H}$ & $\mathrm{CH}_{2} \mathrm{CH}_{2} \mathrm{Cl}$ & 87 & & & & \\
\hline
\end{tabular}


A second attempt to further functionalize the polymer supported pyrimidinone was made. To this aim compound 6a was first chlorinated at position 4 using a procedure already described in solution $^{16}$ and then cleaved using both TFA and Oxone ${ }^{\circledR}$ strategies (Scheme 6).

Treatment of the polymer-bound pyrimidine derivative 9 with 5\% TFA proved to be unsuccessful whereas, using 25\% TFA, 10 was isolated deriving from the cleavage of the ethereal bond of the linker, thus confirming the chlorination at position 4.

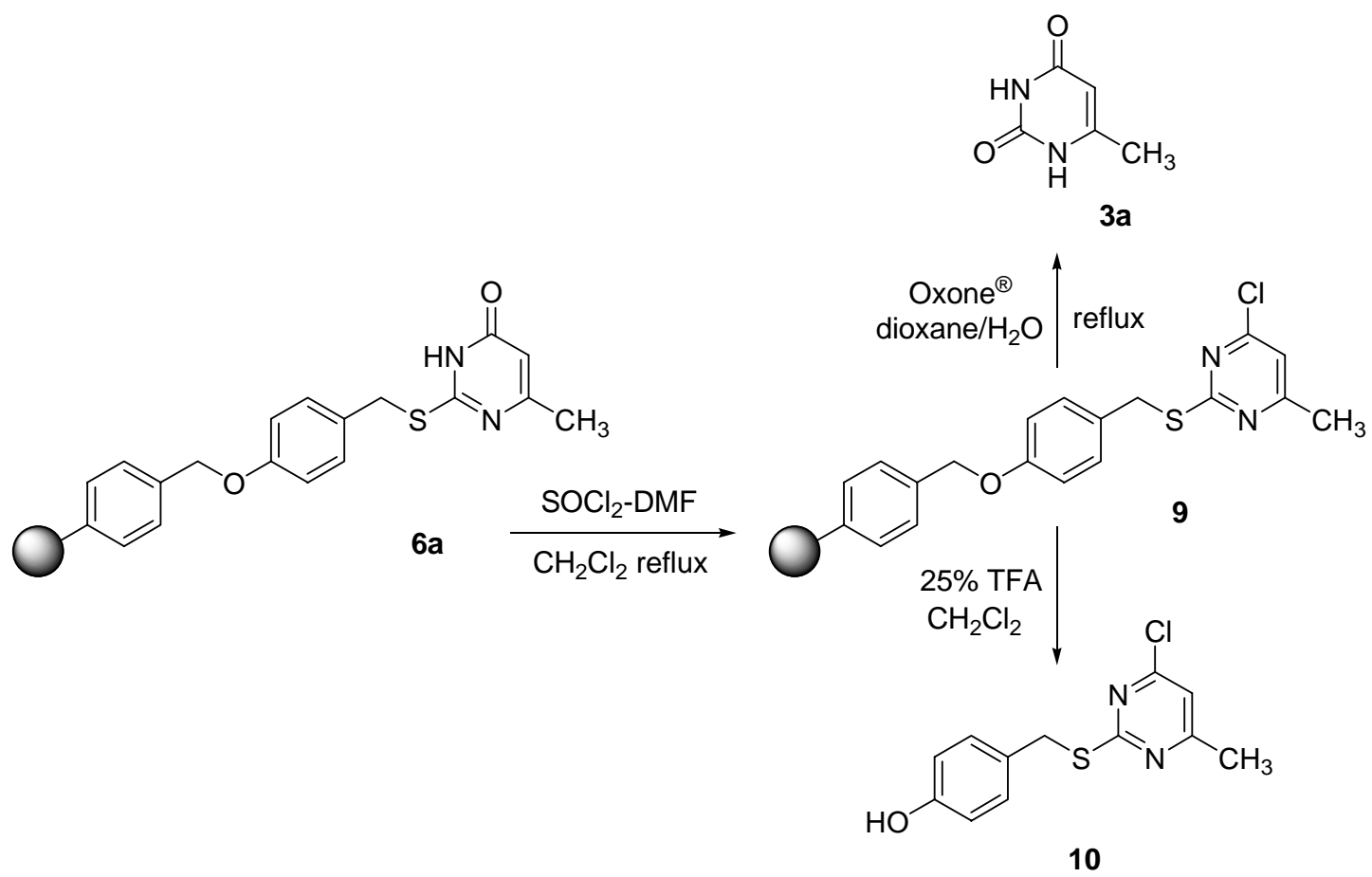

Scheme 6. Functionalization of polymer-supported $6 \mathbf{6}$.

On the other hand, treatment of 9 with Oxone ${ }^{\circledR}$ afforded 6-methyluracil. In order to investigate the step of chlorine displacement, a polymer-supported pyrimidine $\mathbf{1 1}$ (already prepared in our laboratories) not susceptible to a nucleophilic attack was treated with Oxone ${ }^{\circledR}$ (Scheme 7).

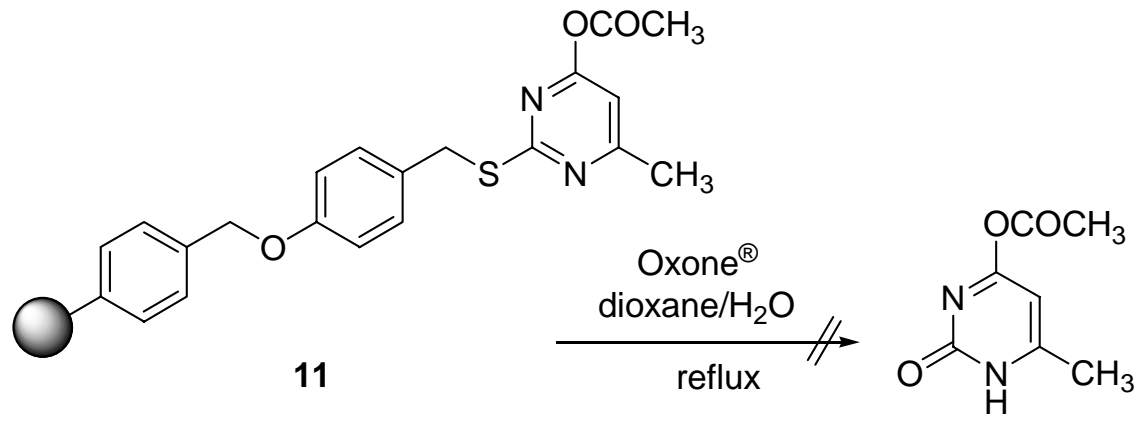

Scheme 7. Attempt for the cleavage of polymer-supported pyrimidine 11. 
No cleavage of the corresponding pyrimidine was observed, thus suggesting that the nucleophilic attack takes place in the solid phase affording a polymer-supported pyrimidinone structure which is, then cleaved by Oxone ${ }^{\circledR}$. In conclusion, we can say that: 1) we are able to activate the pyrimidinone nucleus on solid phase at position 4 , giving rise to a system which can be further functionalised, 2) we can prepare $\mathbf{1 0}$ which represents an interesting pyrimidine scaffold.

\section{Conclusions}

5,6-Disubstituted-2,4(1H,3H)-pyrimidindiones 3a-l, 5,6-disubstituted-2-methoxy-4(3H)-pyrimidinones 4a-d and 5,6-disubstituted-2-thiouracils 7a-d have been prepared in a profitable way through an SPS approach which favourably compares with the corresponding solution-phase synthesis, in that it avoids the laborious purification of the highly polar synthetic intermediates and provides the final compounds in good purity.

The combination of the isothiourea moiety with the Wang linker, therefore, provides the possibility of automation of reactions by using Syncore ${ }^{\circledR}$ and the opportunity to carry out multidirectional resin cleavage from a common polymer-bound intermediate using different cleavage conditions. Therefore, in the final cleavage step an additional element of diversity is incorporated which multiply the number of molecules that can be generated. In conclusion, a versatile and efficient synthetic methodology for a convenient preparation of pyrimidinone and pyrimidindione derivatives using a solid-phase approach has been developed with the use of Syncore $^{\circledR}$ Reactor which, thanks to the high flexibility of possible applications, from vacuum evaporation to parallel filtration, adding of reagents, inert gas and reflux reactions, represents an interesting tool in the hands of a medicinal chemist.

\section{Experimental Section}

General procedures. Unless otherwise stated, all reactions were carried out under an argon atmosphere. Reagents were obtained from commercial suppliers and used without further purifications. Melting points are uncorrected. The ${ }^{1} \mathrm{H}$ NMR spectra were measured at $200 \mathrm{MHz}$. Chemical shifts are reported relative to $\mathrm{CDCl}_{3}$ at $\delta 7.24 \mathrm{ppm}$ and tetramethylsilane at $\delta 0.00 \mathrm{ppm}$. EI and FAB low-resolution mass spectra were recorded with an electron beam of $70 \mathrm{eV}$. Elemental analyses (C, H, N) were performed 'in house'. Büchi Syncore ${ }^{\circledR}$ Polyvap R-24 was used for parallel synthesis and evaporation.

\section{Polymer-bound pyrimidinones 2a-d and 6a-d: classical procedure}

Polymer 1 (3 g, $3.6 \mathrm{mmol}$ functional group), or polymer 5 (3 g, $3 \mathrm{mmol}$ functional group), was suspended in a EtOH/ $\mathrm{H}_{2} \mathrm{O} 1 / 1(150 \mathrm{~mL})$ mixture and swollen for $10 \mathrm{~min}$. $\mathrm{Ca}(\mathrm{OH})_{2}(1 \mathrm{eq})$ and the opportune $\beta$-ketoester (20 eq) were added and the reaction mixture stirred at room temperature. After $24 \mathrm{~h}$ further 0.5 eq of $\mathrm{Ca}(\mathrm{OH})_{2}$ were added, together with additional 20 eq of $\beta$-ketoester. 
After $48 \mathrm{~h}$ other 10 eq of $\beta$-ketoester were added. After $72 \mathrm{~h}$ the polymer was filtered, washed successively with hot $\mathrm{H}_{2} \mathrm{O}(3 \times 10 \mathrm{~mL}), \mathrm{EtOH}(3 \times 10 \mathrm{~mL}), \mathrm{CH}_{2} \mathrm{Cl}_{2}(3 \times 10 \mathrm{~mL})$, and $\mathrm{Et}_{2} \mathrm{O}(3 \mathrm{x}$ $10 \mathrm{~mL}$ ). The reaction was repeated twice; after filtration and washing the polymer-was dried in vacuo at $20{ }^{\circ} \mathrm{C}$ for $4 \mathrm{~h}$.

\section{Polymer-bound pyrimidinones 6a-n: automatic procedure}

Polymer 5 was divided in 12 portions. Each sample of resin $(500 \mathrm{mg}, 0.5 \mathrm{mmol}$ functional group) was swollen in dioxane $(2 \mathrm{~mL})$ for $1 \mathrm{~h}$ shaking at $200 \mathrm{rpm}$, then ethanol $(2 \mathrm{~mL})$ was added and reaction was shaked for an additional hour. A solution of $\mathrm{NaOH}(20 \mathrm{mg}, 0.5 \mathrm{mmol})$ in water $(2 \mathrm{~mL})$ and the opportune $\beta$-ketoester $(2.5 \mathrm{mmol})$ were added into $2 \mathrm{~h}$ time and the reaction mixtures were shaked at room temperature for $24 \mathrm{~h}$. The resins were then filtered, washed successively with $\mathrm{H}_{2} \mathrm{O}(3 \times 50 \mathrm{~mL}), \mathrm{MeOH}(3 \times 50 \mathrm{~mL}), \mathrm{CH}_{2} \mathrm{Cl}_{2}(3 \times 50 \mathrm{~mL})$ and hexane $(50 \mathrm{~mL})$ and dried in vacuo at $20{ }^{\circ} \mathrm{C}$ for $4 \mathrm{~h}$ using Syncore ${ }^{\circledR}$ Filtration Unit and vacuum pump.

\section{Polymer-bound thiopyrimidine 9}

Polymer 6a (1g, 1 mmol functional group) was suspended in dry $\mathrm{CH}_{2} \mathrm{Cl}_{2}(20 \mathrm{~mL})$ and swollen for $10 \mathrm{~min}$. A solution of $\operatorname{SOCl}_{2}(290 \mu \mathrm{L}, 4 \mathrm{mmol})$ in anhydrous DMF (317 $\left.\mu \mathrm{L}, 4.1 \mathrm{mmol}\right)$ was added and the suspension was stirred at reflux temperature for $12 \mathrm{~h}$. The polymer was filtered, washed successively with dry $\mathrm{CH}_{2} \mathrm{Cl}_{2}(3 \times 20 \mathrm{~mL})$, and dry $\mathrm{Et}_{2} \mathrm{O}(3 \times 20 \mathrm{~mL})$ and dried in vacuo at $20{ }^{\circ} \mathrm{C}$ for $4 \mathrm{~h}$.

\section{5,6-Disubstituted pyrimidine-2,4(1H,3H)-diones 3a-d: classical procedure}

Polymer 2 (1g, $1.2 \mathrm{mmol}$ of functional group) or polymer 6 ( $1 \mathrm{~g}, 1 \mathrm{mmol}$ of functional group) was suspended in dioxane $(18 \mathrm{~mL})$ and swollen for $10 \mathrm{~min}$. A solution of Oxone ${ }^{\circledR}(3 \mathrm{eq})$ in $\mathrm{H}_{2} \mathrm{O}$ $(3 \mathrm{~mL})$ was added and the reaction mixture was stirred overnight at reflux temperature. The polymer was then filtered, washed with $\mathrm{MeOH}(3 \times 10 \mathrm{ml})$ and the organic solution evaporated under reduced pressure to give the desired products 3a-d. Reaction was repeated twice in the same conditions.

3a. $\mathrm{mp} 317^{\circ} \mathrm{C}\left(\operatorname{lit}^{17} \mathrm{mp} 320^{\circ} \mathrm{C}\right)$.

3b. $\mathrm{mp} 297-299^{\circ} \mathrm{C}\left(\right.$ lit $\left.^{17} \mathrm{mp} 298-299{ }^{\circ} \mathrm{C}\right)$.

3c. $\mathrm{mp} 278-280{ }^{\circ} \mathrm{C}\left(1 \mathrm{lit}^{18} \mathrm{mp} 280-282^{\circ} \mathrm{C}\right)$.

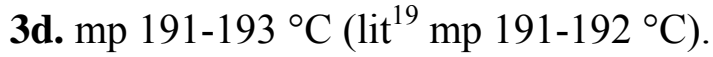

\section{5,6-Disubstituted pyrimidine-2,4(1H,3H)-diones 3a-l: automatic procedure}

Polymer 6 was divided in 12 portions. Each sample (500 mg, $0.5 \mathrm{mmol}$ functional group) was swollen in dioxane $(3 \mathrm{~mL})$ for $1 \mathrm{~h}$, then a solution of Oxone ${ }^{\circledR}(922 \mathrm{mg}, 1.5 \mathrm{mmol})$ in $\mathrm{H}_{2} \mathrm{O}(3 \mathrm{~mL})$ was added and the reaction mixture was shaken overnight at $300 \mathrm{rpm}$ at reflux temperature. 
The resins were filtered by using Syncore ${ }^{\circledR}$ Filtration Unit and the solvent was evaporated by using a Syncore ${ }^{\circledR}$ vacuum pump to yield compounds 3(a-l) in good purity. Reaction was repeated twice in the same conditions.

3e. $\operatorname{mp~} 330-332{ }^{\circ} \mathrm{C}\left(\right.$ lit $\left.^{20} \mathrm{mp} 330-332^{\circ} \mathrm{C}\right)$.

3f. $\mathrm{mp} 308-310^{\circ} \mathrm{C}\left(\mathrm{lit}^{21} \mathrm{mp} 308-309^{\circ} \mathrm{C}\right)$.

3g. $\mathrm{mp} 308-311^{\circ} \mathrm{C}\left(1 \mathrm{it}^{9 \mathrm{~h}} \mathrm{mp} 310^{\circ} \mathrm{C}\right)$.

3h. $\mathrm{mp} 200-201^{\circ} \mathrm{C}\left(1 \mathrm{it}^{22} \mathrm{mp} 199-200^{\circ} \mathrm{C}\right)$.

3i. $\mathrm{mp} 225-228^{\circ} \mathrm{C}\left(\mathrm{lit}^{23} \mathrm{mp} 227-229^{\circ} \mathrm{C}\right)$.

3j. ${ }^{1} \mathrm{H}-\mathrm{NMR}\left(\mathrm{CDCl}_{3}\right): \delta$ 1.52-1.65 (m, 3H); 1.92-2.12 (m, 9H); 2.24--2.32 (m, 3H);

$5.22(\mathrm{~s}, 1 \mathrm{H})$. FABMS (TDEG-GLY) $\mathrm{m} / \mathrm{z} 247(\mathrm{M}+\mathrm{H})^{+}$. Anal. Calcd. for $\mathrm{C}_{14} \mathrm{H}_{18} \mathrm{~N}_{2} \mathrm{O}_{2}$ :

C, 68.27; H, 7.37; N, $11.37 \%$. Found C, 68.22; H. 7.39; N, $11.36 \%$.

3k. mp 269-272 ${ }^{\circ} \mathrm{C}\left(\right.$ lit $\left.^{24} \mathrm{mp} \mathrm{270-272}{ }^{\circ} \mathrm{C}\right)$.

31. $\mathrm{mp} 249-251^{\circ} \mathrm{C}\left(\operatorname{lit}^{25} \mathrm{mp} 249-251^{\circ} \mathrm{C}\right)$.

\section{5,6-Disubstituted 2-methoxypyrimidin-4(3H)-ones 4a-d}

\section{Classical procedure}

Polymer 2 (1 g, 1.2 functional group) or polymer 6 ( $1 \mathrm{~g}, 1 \mathrm{mmol}$ functional group) was suspended in methanol $(18 \mathrm{~mL})$ and swollen for $10 \mathrm{~min}$. Oxone ${ }^{\circledR}(3 \mathrm{eq})$ was added and the reaction mixture was stirred overnight at room temperature. The polymer was then filtered, washed with $\mathrm{MeOH}(3$ $\mathrm{x} 10 \mathrm{~mL}$ ) and the organic solution evaporated under reduced pressure to give the expected product 4a-d. Reaction was repeated twice in the same conditions.

\section{Automatic procedure}

Polymer 6 was divided in 4 portions. Each sample (500 mg, $0.5 \mathrm{mmol}$ functional group) was swollen in methanol $(6 \mathrm{~mL})$ for $1 \mathrm{~h}$, then Oxone ${ }^{\circledR}(922 \mathrm{mg}, 1.5 \mathrm{mmol})$ was added and the reaction was shaked overnight at $300 \mathrm{rpm}$ at reflux temperature.

The polymer was filtered by using Syncore ${ }^{\circledR}$ Filtration Unit and the filtrate was evaporated by using Syncore $^{\circledR}$ vacuum pump to afford compounds 4a-d in good purity. Reaction was repeted twice in the same conditions.

4a. $\mathrm{mp} 207-209^{\circ} \mathrm{C}\left(1 \mathrm{lit}^{10} \mathrm{mp} 207^{\circ} \mathrm{C}\right)$.

4b. $\mathrm{mp} 199-200{ }^{\circ} \mathrm{C}\left(1 \mathrm{it}^{10} \mathrm{mp} 198^{\circ} \mathrm{C}\right)$.

4c. ${ }^{1} \mathrm{H}-\mathrm{NMR}\left(\mathrm{CDCl}_{3}\right)$ : $\delta 3.75$ (s, 2H); 3.95 (s, 3H); 5.87 (s, 1H); 7.17-7.32 (m, 5H).

FABMS (TDEG-GLY) $\mathrm{m} / \mathrm{z} 217(\mathrm{M}+\mathrm{H})^{+}$. Mp 208-210 ${ }^{\circ} \mathrm{C}$. Anal. Calcd. for

$\mathrm{C}_{12} \mathrm{H}_{12} \mathrm{~N}_{2} \mathrm{O}_{2}$ : C, 66.65; H, 5.59; N, $12.95 \%$. Found C, 66.70; H. 5.54; N, $12.96 \%$.

4d. $\mathrm{mp} 120-122^{\circ} \mathrm{C}\left(\operatorname{lit}^{9 \mathrm{i}} \mathrm{mp} 118-122^{\circ} \mathrm{C}\right)$.

\section{5,6-Disubstituted 2-thioxo-2,3-dihydropyrimidin-4(1H)-ones 7a-d}

\section{Classical procedure}

Polymer 6 (1g, $1 \mathrm{mmol}$ functional group) was suspended in dry $\mathrm{CH}_{2} \mathrm{Cl}_{2}(19 \mathrm{~mL})$ and swollen for $10 \mathrm{~min}$. TFA $(1 \mathrm{~mL})$ was then added and the suspension was stirred at room temperature for $12 \mathrm{~h}$. 
The resin was filtered, washed with $\mathrm{MeOH}(3 \times 10 \mathrm{~mL}), \mathrm{CHCl}_{3}(2 \times 10 \mathrm{~mL}), \mathrm{CH}_{2} \mathrm{Cl}_{2}(2 \times 10 \mathrm{~mL})$ and $\mathrm{Et}_{2} \mathrm{O}(3 \times 10 \mathrm{ml})$. The organic solution was concentrated in vacuo to give 7 a-d in good purity.

\section{Automatic procedure}

Polymer 6 was divided in 4 portions. Each sample (500 $\mathrm{mg}, 0.5 \mathrm{mmol}$ functional group) was swollen in dry $\mathrm{CH}_{2} \mathrm{Cl}_{2}(5.7 \mathrm{~mL})$ for $1 \mathrm{~h}$, then TFA $(0.3 \mathrm{~mL})$ was added and the reaction was shaked for $12 \mathrm{~h}$ at $200 \mathrm{rpm}$ at room temperature. The resin was then filtered by using Syncore ${ }^{\circledR}$ Filtration Unit and TFA was evaporated by using Syncore ${ }^{\circledR}$ vacuum pump to afford compounds 7a-d in good purity.

7a. $\mathrm{mp} 221-224\left(\mathrm{lit}^{26} \mathrm{mp} 223-224^{\circ} \mathrm{C}\right)$.

7b. $\mathrm{mp} 284-286^{\circ} \mathrm{C}\left(\mathrm{lit}^{27} \mathrm{mp} 283-285^{\circ} \mathrm{C}\right)$.

7c. $\mathrm{mp} 221-224^{\circ} \mathrm{C}\left(\mathrm{lit}^{27} \mathrm{mp} 223-224^{\circ} \mathrm{C}\right)$.

7d. ${ }^{1} \mathrm{HNMR}\left(\mathrm{CDCl}_{3}\right) \delta 1.21(\mathrm{t}, J=6.8 \mathrm{~Hz}, 3 \mathrm{H}), 3.51(\mathrm{~s}, 2 \mathrm{H}), 4.14(\mathrm{q}, J=6.81 \mathrm{~Hz}, 2 \mathrm{H}), 6.14$ (s, 1H). FABMS (TDEG-GLY) m/z $215(\mathrm{M}+\mathrm{H})^{+}$. Mp 160-163 ${ }^{\circ} \mathrm{C}$. Anal. Calcd. for $\mathrm{C}_{8} \mathrm{H}_{10} \mathrm{~N}_{2} \mathrm{O}_{3} \mathrm{~S}: \mathrm{C}$, 44.85; H, 4.70; N, 13.08 \%. Found: C, 44.87; H, 4.67; N. $13.11 \%$.

\section{2-(4-Hydroxyphenylmethylthio)-4-chloro-6-methyl-pyrimidine (10).}

Polymer 9 (500 mg, $0.5 \mathrm{mmol}$ functional group) was suspended in dry $\mathrm{CH}_{2} \mathrm{Cl}_{2}$ (7.5 mL) and swollen for $10 \mathrm{~min}$. TFA $(2.5 \mathrm{~mL})$ was then added and the suspension was stirred at room temperature for $12 \mathrm{~h}$. The resin was filtered, washed with $\mathrm{MeOH} / \mathrm{CHCl}_{3}(3 \times 10 \mathrm{~mL}), \mathrm{CHCl}_{3}$ $(2 \times 10 \mathrm{~mL}), \mathrm{CH}_{2} \mathrm{Cl}_{2}(2 \times 10 \mathrm{~mL})$ and $\mathrm{Et}_{2} \mathrm{O}(3 \times 10 \mathrm{~mL})$. The organic solution was concentrated in vacuo to give $\mathbf{1 0}(30 \%)$ in good purity.

${ }^{1} \mathrm{H}-\mathrm{NMR}\left(\mathrm{CDCl}_{3}\right) \delta 2.42(\mathrm{~s}, 3 \mathrm{H}), 4.37(\mathrm{~s}, 2 \mathrm{H}) ; 7.20-7.226(\mathrm{~m}, 5 \mathrm{H})$. FABMS (TDEG-GLY) $\mathrm{m} / \mathrm{z}$ $267(\mathrm{M}+\mathrm{H})^{+}$, 269. Anal. Calcd. for $\mathrm{C}_{12} \mathrm{H}_{11} \mathrm{ClN}_{2} \mathrm{OS}$ : C, 54.03; H, 4.16; N. $10.50 \%$. Found. C, 54.00; H. 4.17; N, $10.52 \%$.

\section{Acknowledgements}

The University of Siena (PAR 2001) is gratefully acknowledged. M.B. wishes to thank the Merck Research Laboratories for the 2002 Academic Development Program (ADP) Chemistry Award.

\section{References}

1. (a) Giles, F. J. Expert Rev. Anticancer Ther. 2002, 2, 261. (b) Knapp, S. Chem. Rev. 1995, 95, 1859. (c) Felczak, K.; Drabikowska, A. K.; Vilpo, J. A.; Kulikowski, T.; Shugar, D. J. Med. Chem. 1996, 39, 1720.

2. Pontikis, R.; Benhida, R.; Aubertin, A. M.; Grierson, D. S.; Monneret, C. J. Med. Chem. 1997, 40, 1845. 
3. Robins, R. K.; Revankar, G. R. Med. Res. Rev. 1985, 5, 273.

4. Botta, M.; Artico, M.; Massa, S.; Gambacorta, A.; Marongiu, M. E.; Pani, A.; La Colla, P. Eur. J. Med. Chem. 1992, 27, 251.

5. (a) Szczech, G. M.; Furman, P.; Painter, G. R.; Barry, D. W.; Borroto-Esoda, K.; Grizzle, T. B.; Blum, M. R.; Sommadossi, J.-P.; Endoh, R.; Niwa, T.; Yamamoto, M.; Moxham C. Antimicrob. Agents Chemother. 2000, 44, 123. (b) Giles, F. J.; Feldman, E. J.; Roboz, G. J.; Larson, R. A.; Mamus, S. W.; Cortes, J. E. ; Verstovsek, S.; Federl, S.; Talpaz, M.; Beran, M.; Albitar, M.; O’Brien, S. M.; Kantarjian, H. M. Leuk. Res. 2003, 27, 1091. (c) Giles, F. J. Expert Rev. Anticancer Ther. 2002, 2, 261. (d) Toyohara, J.; Hayashi, A.; Sato, M.; Gogami, A.; Tanaka, H.; Haraguchi, K.; Yoshimura, Y.; Kumamoto, H.; Yonekura, Y.; Fujibayashi, Y. Nucl. Med. Biol. 2003, 30, 687. (e) Mangner, T. J.; Klecker, R. W.; Anderson, L.; Shields, A. F. Nucl. Med. Biol. 2003, 30, 215. (f) Toyohara, J.; Fujibayashi, Y. Nucl. Med. Biol. 2003, 30, 681. (g) Dieterle, F.; Müller-Hagedon, S.; Liebich, H. M.; Gauglitz, G. Artif. Intell. Med. 2003, 28, 265.

6. (a) Rowley, D. C.; Hansen, M. S. T.; Rhodes, D.; Striffer, C. A.; Ni, H.; McCammon, J. A.; Bushman, F. D.; Fenical, W. Bioorg. Med. Chem. 2002, 10, 3619. (b) Arnaud, A.; Fontana, L.; Angulo, A. J.; Gil, Á.; López-Pedrosa, J. M. Clin. Nutr. 2003, 22, 391. (c) Gallant, J. E. J. Clin. Virol. 2002, 25, 317.

7. (a) Molina, P.; Aller, E.; Lorenzo, A.; Lopez-Cremades, P.; Rioja, I.; Ubeda, A.; Terencio, M. C.; Alcaraz, M. J. J. Med. Chem. 2001, 44, 1011. (b) Kumar, A.; Sinha, S.; Chauhan, P. M. S. Bioorg. Med. Chem. Lett. 2002, 12, 667.

8. (a) Bher, J.-B.; Gourlain, T.; Helimi, A.; Guillerm, G. Bioorg. Med. Chem. Lett. 2003, 13, 1713. (b) De Koning, H. P.; Al-Salabi, M. I.; Cohen, A. M.; Coombs, G. H.; Wastling, J. M. Int. J. Paras. 2003, 33, 821. (c) Behr, J.-B.; Gourlain, T.; Helimi, A.; Guillerm, G. Bioorg. Med. Chem. Lett. 2003, 13, 1713. (d) De Koning, H. P.; Al-Salabi, M. I.; Cohen, A. M.; Coombs, G.; Wastling, J. M. Int. J. Paras. 2003, 33, 821.

9. (a) Stasi, L. P.; Mugnaini, C.; Alcaro, S.; Corelli, F.; Botta, M. Heterocycles 2003, 61, 403.

(b) Mugnaini, C.; Botta, M.; Coletta, M.; Corelli, F.; Focher, F.; Marini, S.; Renzulli, M. L.; Verri, A. Bioorg. Med. Chem. 2003, 11, 357. (c) Paolini, L.; Petricci, E.; Corelli, F.; Botta, M. Synthesis, 2003, 1039. (d) Petricci, E.; Botta, M.; Corelli, F.; Mugnaini, C. Tetrahedron Lett. 2002, 43, 6507. (e) Petricci, E.; Renzulli, M.; Radi, M.; Corelli, F.; Botta, M. Tetrahedron Lett. 2002, 43, 9667. (f) Botta, M.; Corelli, F.; Petricci, E.; Seri, C. Heterocycles 2002, 56, 369. (g) Saladino, R.; Crestini, C.; Palamara, A. T.; Danti, M. C.; Manetti, F.; Corelli, F.; Garaci, E.; Botta, M. J. Med. Chem. 2001, 44, 4554. (h) Botta, M. Corelli, F.; Maga, G.; Manetti, F.; Renzulli, M.; Spadari, S. Tetrahedron 2001, 57, 8357. (i) Botta, M.; Occhionero, F.; Nicoletti, R.; Mastromarino, P.; Conti, C.; Magrini, M.; Saladino, R. Bioorg. Med. Chem. 1999, 7, 1925.

10. Botta, M.; Cavalieri, M.; Ceci, D.; De Angelis, F.; Finizia, G.; Nicoletti, R. Tetrahedron 1984, 40, 3313.

11. (a) Botta, M.; Saladino, R.; Occhionero, F.; Nicoletti, R. Trends in Organic Chemistry 1995, 5, 57. (b) Botta, M.; Saladino, R.; Lamba, D.; Nicoletti, R. Tetrahedron 1993, 49, 6053. 
12. Saladino, R.; Ciambecchini, U.; Maga, G.; Mastromarino, P.; Conti, C.; Botta, M. Bioorg. Med. Chem. 2002, 10, 2143.

13. (a) Edwards, P. Drug Discov. Today 2003, 8, 762. (b) Ganesan, A. Drug Discov. Today 2002, 7, 47. (c) Macdonald, S. J. F.; Dowle, M. D.; Harrison, L. A.; Clarke, G. D. E.; Inglis, G. G. A.; Johnson, M. R.; Shah, P.; Smith, R. A.; Amour, A.; Fleetwood, G.; Humphreys, D. C.; Molloy, C. R.; Dixon, M.; Godward, R. E.; Wonacott, A. J.; Singh, O. M. P.; Hodgson, S. T.; Hardy, G. W. J. Med. Chem. 2002, 45, 3878. (d) Lewis, W. G.; Green, L. G.; Grynszpan, F.; Radic, Z.; Carlier, P. R.; Taylor, P.; Finn, M. G.; Sharpless, K. B. Angew. Chem., Int. Ed. 2002, 41, 1053. (e) Ragan, J.; Breitfelder, S.; Cirillo, P.; Gilmore, T.; Graham, A. G.; Hickey, E.; Klaus, B.; Madwed, J.; Moriak, M.; Moss, N. J. Med. Chem. 2002, 45, 2994. (f) Dolle, R. J. Comb. Chem. 2002, 4, 369.

14. (a) Wills, A. J.; Balasubramanian, S. Current Opin. Chem. Biol. 2003, 7, 346. (b) Waldmann, H. Bioorg. Med. Chem. 2003, 11, 3045. (c) Yu, Z.; Bradley, M. Curr. Opin. Chem. Biol. 2002, 6, 347. (d) Ley, S. V.; Baxendale, I. R.; Bream, R. N.; Jackson, P. S.; Leach, A. G.; Longbottom, D. A.; Nesi, M.; Scott, J. S.; Storer R. I.; Taylor, S. J. J. Chem. Soc., Perkin Trans. 1 2000, 3815. (e) Bhattacharyya, S. Combin. Chem. High Throughput Screening 2000, 3, 65. (f) Vaino, A. R.; Janda, K. D. J. Comb. Chem. 2000, 2, 579.

15. Kappe, C. O. Bioorg. Med. Chem. Lett. 2000, 10, 49.

16. Botta, M.; De Angelis, F.; Finizia, G.; Gambacorta, A.; Nicoletti, R. Synth. Comm. 1985, 15, 27.

17. Mikolajczyk, M.; Luczak, J. Synthesis 1974, 491.

18. Mogilaiah, K.; Chowdary, D. S.; Reddy, P. R. Synth. Comm. 2002, 32, 851.

19. Hilbert, G. E. J. Amer. Chem. Soc. 1932, 54, 2076.

20. Corrnforth, J. W.; Huang, H. T. J. Chem. Soc. 1948, 1988.

21. Martinez, A. G.; Fernandez, A. H.; Jimenez, F. M.; Martinez, P. J. M.; Martin, C. A.; Subramanian, L. R. Tetrahedron 1996, 52, 7973.

22. Evans, R. M.; Jones, P. C.; Palmer, P. J.; Stephens, F. F. J. Chem. Soc. 1956, 4106.

23. Helmkamp, G. K.; Kondo, N. S. Biochim. Biophys. Acta 1968, 242.

24. Bergman, E. D.; Cohen, S.; Shahak, I. J. Chem. Soc. 1959, 3278.

25. Klein, R. S.; Fox, J. J. J. Org. Chem. 1972, 72, 4381.

26. Niedballa, U.; Vorbrüggen, H. J. Org. Chem. 1974, 39, 3654.

27. Anderson, G. W.; Halverstadt, I. F.; Miller, W. H.; Roblin, R. O. J. Amer. Chem. Soc. 1945, 67, 2197. 